\title{
İflasın Ertelenmesi ve Borca Batıklık: Bir Uygulama *
}

\section{The Postponement of Bankruptcy and Overindeptedness: An Application}

\author{
Fikret Otlu ${ }^{a}$, Şakir İşleyen ${ }^{\text {b,**, Hamza Kaya }}{ }^{\mathrm{c}}$ \\ ${ }^{a}$ Prof. Dr., İnönü Üniversitesi, İktisadi ve İdari Bilimler Fakültesi, İşletme Bölümü, 44280, Malatya/Türkiye. \\ ORCID: 0000-0002-1264-1732 \\ b Dr. Öğr. Üyesi, Van Yüzüncü Yıl Üniversitesi, İktisadi ve İdari Bilimler Fakültesi, Ekonometri Bölümü, 65080, Van/Türkiye. \\ ORCID: 0000-0002-8186-1990 \\ c İnönü Üniversitesi, Sosyal Bilimler Enstitüsü, 44280, Malatya/Türkiye. \\ ORCID: 0000-0002-3432-3356
}

\section{MAKALE BILGİSI}

\section{Makale Geçmişi:}

Başvuru tarihi: 10 Temmuz 2018

Düzeltme tarihi: 28 Temmuz 2018

Kabul tarihi: 02 Ağustos 2018

\section{Anahtar Kelimeler:}

İflas

İflasın Ertelenmesi

Borca Batıklık

\section{ARTICLE INFO}

\section{Article history:}

Received July 10, 2018

Received in revised form July 28, 2018

Accepted August 2, 2018

\section{Keywords:}

Bankruptcy

Postponement of Bankruptcy

Overindeptedness

\section{ÖZ}

İflasın ertelenmesi, borca batık durumda bulunan, şirket tarafından sunulan; somut öngörüler içeren, ciddi ve inandırıcı bir iyileştirme projesi çerçevesinde bu durumdan kurtulması kuvvetle muhtemel bulunan kooperatiflerle sermaye şirketleri için öngörülmüş bir hukuki korunma yoludur. Borca batıklık ise şirket aktifleri -yıllık bilançoda olduğu gibi defter değerleriyle değil- fakat gerçek (olası satış değerleri) değerleriyle değerlemeye tabi tutulsalar bile alacaklıların, alacaklarını alamamaları, yani şirketin borç ve tahhütlerini karşılayamaması durumudur. "İflasın Ertelenmesi ve Borca Batıklık: Bir Uygulama" başlıklı bu çalışmada, genel olarak iflas, iflasın ertelenmesi, iflasın ertelenmesinin şartları ve borca batıklık konuları ele alınarak Van ilinde iflas erteleme talebinde bulunan bir şirketin borca batıklık bilançosu düzenlenerek, değerlendirilmiştir.

\begin{abstract}
A B S T R ACT
The postponement of bankruptcy is the legal protection for the associations and financial companies which are overindepted and are highly-likely to be recovered that companies present reliable forecasts, include convincing and serious betterment project to be saved. The legal situation of overindeptedness is assets of the company which could not fulfill the payments to debate even by evaluating assets according to their real value (potential selling value) - opposite to evaluating according to annual financial statement which evaluates them according to book value - so the company cannot fulfill the commitments and debts. In this study with the title of "The Postponement of Bankruptcy and Overindeptedness: An Application"; bankruptcy, postponement of bankruptcy, terms of postponement of bankruptcy and overindeptedness are being approached by examining a Van's company's demand of postponement of bankruptcy and issuing an overindeptedness balance sheet for them to evaluate their works.
\end{abstract}

\section{Giriş}

İflas sistemi, eski zamanlardan bu yana özel bir önem arz etmektedir. Roma hukukunda borçlunun tüm alacaklıların eline bırakılması, önce bedeni üzerinde daha sonra tüm mallarının zilyetliğinin borçluya geçirilmesi şeklinde başlayan uygulama, tarih içinde sadece borçlunun mal varlığıyla sorumluluğuna ve külli bir tasfiye usulüne dönüşmüştür (Atalay, 2010). İflas, Arapça kökenli bir sözcük olan “fülüs”a; yani değer ifade etmeyen anlamına gelen bir kökten türemiş ve "parayı pulu bitirmek" şeklinde tanımlanmıştır (Atalay, 2010; Kırtıloğlu, 2007). İflasa tabi kişiler kural olarak tacirlerdir. Gerçek kişiler gibi tüzel kişilerde tacir olabilir.

İflastan sadece işletme sahipleri değil, alıcılar, çalışanlar, satıcılar, kredi kurumları ve devlet olmak üzere pek çok taraf zarar görür. $\mathrm{Bu}$ zararın önüne geçmek için mevzuatımız,

\footnotetext{
* Bu çalışma, 2017 yılında Yüzüncü Yıl Üniversitesi Sosyal Bilimler Enstitüsü tarafından kabul edilen “Ifflasın Ertelenmesi ve Borca Batıklık: Bir Uygulama" adlı Yüksek Lisans tezinden türetilmiştir.

** Sorumlu yazar/Corresponding author.

e-posta: sakirisleyen@yyu.edu.tr
} 
sermaye şirketleri ve kooperatifler için bir açıdan, iflastan kurtuluş yolu öngörmüştür. $\mathrm{Bu}$ kurtuluş yolu, "iflasın ertelenmesi” müessesesi tarafından sağlanmaktadır.

İflasın ertelenmesi, borca batık bir halde olan sermaye şirketi/kooperatifin ekonomik durumunun iyileşmesi muhtemel olması durumunda borçlu şirketin veya kooperatifin iflasının önüne geçmesini sağlayan bir müessesedir. $\mathrm{Bu}$ bağlamda iflas erteleme müessesesinin temel amacı, finansal yapısı bozulmuş ve iflası istenmiş olan bir sermaye şirketinin, gerekli tedbirler ve iyileştirici önlemler alınarak, varlığını ve faaliyetlerini devam ettirmesinin sağlanmasıdır (Bitlisli ve Yılmaz, 2016).

Bu çalışmanın amacı, 2004 sayılı İcra ve İflas Kanunu ile 6102 sayılı Türk Ticaret Kanunu hükümleri gereğince iflasın ertelenmesinin şartları ve borca batıklık incelenerek Van ilinde iflas erteleme talebinde bulunan bir firmanın borca batıklık bilançosu ile talebini incelemektir.

\section{Genel Olarak İflas}

Şirketlerin varlığının sona ermesi durumuna iflas denir. İflastan menfi yönde etkilenen birçok taraf vardır. Bunlar; işletme sahipleri, personeller, kreditörler, alıcılar ve satıcılar olabileceği gibi devlet de sayılabilir (Özkan, 2013).

Kanunda iflas yolları takipli ve takipsiz iflas olarak düzenlendikten sonra, takipsiz (doğrudan) iflas da kendi içinde alacaklının ve borçlunun talebiyle doğrudan iflas olarak ikiye ayrılmıştır. Takipsiz iflası takipli iflastan ayıran başlıca fark, bu yola başvurabilmek için kanunun aradığı özel iflas sebeplerinin de gerçekleşmiş olmasıdır (Özekes, 2007).

İflasa tabi kişiler kural olarak tacirlerdir. Gerçek kişiler gibi tüzel kişilerde (kollektif, komandit, anonim, limited ve kooperatif şirketler) tacir olabilir. Buna göre iflasa tabi kişiler; tacirler, tacir olmamakla birlikte tacirler hakkındaki hükümlere tabi olanlar ve yine tacir olmadıkları halde özel kanun hükümlerine göre iflasa tabi olanlar şeklinde sinıflandırılır.

İflas tasfiyesinin normal son bulma şekli, iflasın kapanması şeklinde olur. Fakat iflas tasfiyesi devam ederken bazı sebeplerle iflas kaldırılabilir ve bununla da iflas sona erer.

Şirketlerin iflas etmesi sadece kendi tüzel kişiliklerini etkilemekle kalmamakta bunun yanında, kendisiyle ticari ilişkisi bulunan alacaklılarını, çalışanlarını hatta iflas etmiş şirketin büyüklüğü oranında faaliyet gösterdiği piyasaları da olumsuz yönde etkilemektedir. Bu durumda borca batık olan şirketlerin; kendisinin, alacaklıların, çalışanlarının ve piyasaların, iflasın olumsuz neticelerinden etkilenmemesi açısından iflas erteleme müessesesi hayati önem taşımaktadır (Şimşek, 2014).

\section{3. İflasın Ertelenmesi}

İflâsın ertelenmesi müessesesi, hukukumuzda uzun zamandan beri mevcut olan, ancak fazla işlerliği olmayan bir kurumdu.

Ülkemizde ekonomi alanında bazı yapısal reformların yapılması zorunluluğu iki binli yılların başında ortaya çıkan ekonomik krizle oldu. Hukuksal alanda gerekli değişikliklerin yapılması, ekonomi alanında gerçekleştirilmesi planlanan yapısal reformların başarılı olması için zorunluydu. Bu nedenle 2002 yılında mali sektöre olan borçların yeniden yapılandırılmasının sağlanmasına yönelik İstanbul Yaklaşımı olarak ifade edilen 4743 sayılı kanun çıkarıldı. Hemen sonrasında 2003 ile 2004 yıllarında 4949 ve 5092 sayılı Kanunlar da çıkarılarak yürürlüğe girdi.

İflasın ertelenmesi kurumu, iki binli yıllarda çıkarılan kanunlar ile sermaye şirketlerine ve kooperatiflere işlerlik kazandırmış ve hukukî bir çare olmuştur. Daha önce Türk Ticaret Kanunu'nun 324/2 maddesinde ve Kooperatifler Kanunu'nun 63'üncü maddesinde yetersiz bir şekilde düzenlenen ve bu açıdan işlevsiz bir durumda bulunup unutulan iflâsın ertelenmesi kurumu, 4949 sayılı Kanun ile İcra ve İflâs Kanunu'na eklenmiştir. İflâsın ertelenmesinin İcra ve İflâs Kanunu'nun 179'uncu maddesinde ayrıntılı olarak düzenlenmesi ile birlikte, bu kurum; uygulamada en çok rağbet gören müesseselerden birisi olmuştur.

İflasın ertelenmesi müessesesi, İİK Tadil Komisyonunda detaylı olarak ele alınmış ve İsviçre'deki gelişmeler paralelinde, hatta bu gelişmeleri aşacak şekilde yeniden düzenlenmiştir (Öztek, 2006). Bu yeni düzenlenme ile ödeme güçlüğü içerisinde bulunan sermaye şirketleri veya kooperatiflere iflastan kurtulmaları için kanunla son bir şans verilmiştir (Özalp, 2013).

İflasın ertelenmesi müessesinin amacı hakkında öğretide çeşitli görüşler ortaya atılmıştır. $\mathrm{Bu}$ görüşler arasındaki çeşitlilik, iflasın ertelenmesi müessesinin kanunen düzenlenmesinin öncelikli amacının borçluları m1, alacaklıları mı, yoksa kamu menfaatinin korunması mi olduğu hakkındadır (Eroğlu, 2014).

İflasın ertelenmesinin amacı bir Yargitay kararında; “ sermaye şirketinin ve kooperatifin ekonomi içinde kalarak faaliyetine devamını sağlamak ve alacaklıları iflasa bağlı olumsuz sonuçlardan etkilenmesinden korumak" olduğu belirtilmiştir (Bitlisli ve Yılmaz, 2016). Mezkûr kararla sermaye şirketi ve kooperatifin iflasının ertelenmesiyle; ödeme güçlüğü içinde olan şirketle birlikte şirketten alacaklı olanların da çıkarlarının gözetildiği açıkça görülmektedir (Güngör, 2016). Bu bağlamda, iflasın ertelenmesi, yalnızca borca batık olan şirket veya kooperatifin ödemelerini erteleyerek normal faaliyetine devam etmesini değil, borçlu şirket veya kooperatiften alacaklı olan tedarikçi, taşeron, işçi, finans kuruluşu ve personel için iflasa nispeten bir tahsilat umudu veya daha olumlu bir netice doğurmaktadır (Aslanoğlu vd., 2014; Arslan, 2008).

Erteleme kararı üzerine borçlu aleyhine hiçbir takip yapılamamakta ve karardan önce başlamış olan takipler de durmaktadır. Bu süre içinde ihtiyati tedbir ve ihtiyati haciz kararları uygulanamayacak; bir takip muamelesi ile kesilebilen zaman aşımı ve hak düşüren müddetler de işlenemeyecektir. Erteleme sırasında taşınır, taşınmaz veya ticari işletme rehiniyle temin edilmiş alacaklar nedeniyle rehinin paraya çevrilmesi yoluyla takip başlatılabilir veya başlamış olan takiplere devam edilebilir. Ancak yapılan bu takipte muhafaza tedbirleri uygulanamayacak ve rehinli malların satış işlemi gerçekleştirilemeyecektir (Diril, 2014). 


\section{1. İflasın Ertelenmesinin Şartları}

İflasın ertelenmesinin gerçekleşmesi için bir takım şartları bulunmaktadır. Bunlar; borçlunun sermaye şirketi veya kooperatif olması, borca batıklık durumunun mahkemeye bildirilmesi, borçlunun mali durumunun iyileştirilmesi ümidinin bulunması, alacaklıların durumu iflasın açılmasına oranla daha kötü bir duruma sokulmaması, iflasın ertelenmesinin talep edilmesi, iyileştirme projesinin mahkemeye sunulması, fevkalade mühletten yararlanılmamış olması, iflasın erteleme masraflarının mahkeme veznesine depo edilmesi ve şirketin veya kooperatifin mahkemece iflasın ertelenmesine layık görülmesi gibi şartlar sayılabilir.

\subsubsection{Borçlunun Sermaye Şirketi veya Kooperatif Olmast}

Yasal düzenleme, iflas erteleme firsatını, iflasa tabi olan bütün şahıslar bakımından değil, ticaret şirketlerinden sadece sermaye şirketleri ve kooperatifler için kabul etmiştir (Güngör, 2016; Çetin, 2010). Sermaye şirketleri; anonim şirketinden, limited şirketinden ve sermayesi paylara bölünmüş komandit şirketinden ibarettir (TTK, 2011). Dolayısıyla borca batıklık sebebiyle sermaye şirketi olmayan ticaret şirketleri ve gerçek kişi tacirler doğrudan doğruya iflas yoluna gidemeyecekleri gibi iflasın ertelenmesi de talep edemeyeceklerdir (Eroğlu, 2014).

\subsubsection{Sermaye Sirketi veya Kooperatifin Borca Batık Olmast}

İflasın ertelenmesinin en önemli ve ön koşulu, sermaye şirketleri ve kooperatiflerin borca batı bir durumda olmasıdır (Beylik, 2011; Diril; 2014). Bu zorunlu bir koşuldur. Zira borca batı olmayan bir sermaye şirketi/kooperatif iflasın ertelenmesini talep edemez (Diril, 2014).

Kanun koyucu, borca batıklık kavramı yerine şirket aktiflerinin alacaklıların alacaklarını karşılamaya yetmemesi (TTK, 2011) veya şirket borçlarının şirket mevcudundan fazla olması (TTK, 2011) ifadelerini kullanmıştır (Güçlü, 2016).

İflasın ertelenmesinin talep edilebilmesi için, öncelikle borca batıklığı muhtemel gösteren somut ve hukuki deliller ibraz edilmesi gerekir. Bunun için sermaye şirketinin aktif kısmının muhtemel satış değerleri üzerinden bir ara bilançosu düzenlenir. Borca batıklık olgusu bir ara bilançodan veya son yılın bilançosundan anlaşılır (Dumanoğlu, 2011; Beylik, 2011).

Borca batıklık bilançosundan hareketle sermaye şirketi/kooperatifin aktifi borçlarını karşılamaya yetmediğinde, burada yönetim kurulu aktif ile borç arasındaki açığın ne kadar olduğuna bakmadan sermaye şirketi veya kooperatifin iflasını istemek zorunda kalır. Doktrinde yapılan bir yoruma göre, mahkemeye tevdi edilen borca batıklık beyanında borçların, aktifi 1 TL kadar aşmış olması bile yeterli görülmektedir. Yargitay verdiği bir kararda, sermaye şirketi veya kooperatifin iyileştirilmesinin mümkün olması halinde ve aktiflerin borçları karşılama oranı yüzde 20-25 seviyesinin altına düşmediği takdirde iflasın ertelenmesini kabul ettiğini belirtmiştir. Aksi halde iyileștirilmesi mümkün olmayacak şekilde borca batmıș bir sermaye şirketi veya kooperatifin, iflasının ertelenmesi talep edilemeyecektir (Y. 19.HD. 25/5/2000, 2000/2197 E., 2000/3957 K.; Uzay, 2008; Y1lmaz, 2009; Y1ld1z, 2016).

\subsubsection{Borca Batıklık Bilançosu Örneği}

Bir firma, bazı nedenlerden dolayı borca batık olduğunu tahmin ederek ara bilanço çıkartmıştır. $\mathrm{Bu}$ nedenle örneğimizde; bilirkişiler tarafından hazırlanan, rayiç (gerçek) değerler üzerinden borca batıklık bilançosu gösterilmiştir.

Iflas erteleme talebi ile mahkemeye başvuran, inşaat sektörüyle uğraşan XYZ İnşaat Sanayi ve Ticaret Limited Şirketi'nin iflas erteleme talebine ilişkin mahkemeye tevdi ettiği ara bilanço ve mahkemece yaptırılan bilirkişi incelemesi sonunda şirketin borca batıklığa esas bilançosu aşağıdaki tabloda düzenlenmiştir;

Tablo 1. XYZ Şirketinin Ara Bilançosu ve Borca Batıklığa Esas Bilançosu (Aktifler)

\begin{tabular}{|c|c|c|}
\hline & Ara Bilanço & $\begin{array}{c}\text { Borca } \\
\text { Batıklık } \\
\text { Bilançosu }\end{array}$ \\
\hline Aktifler & Kayıtlı Değer & Rayiç Değer \\
\hline I. Dönem Varlıklar & $5.985 .018,70$ & $4.075 .668,64$ \\
\hline A. Hazır Değerler & $30.201,87$ & $30.201,87$ \\
\hline 1. Kasa & $8.000,88$ & $8.000,88$ \\
\hline 2. Bankalar & $22.200,99$ & $22.200,99$ \\
\hline B. Ticari Alacaklar & $3.862 .703,06$ & $1.953 .353,00$ \\
\hline 1. Alıcilar & $1.087 .153,00$ & $1.087 .153,00$ \\
\hline 2. Verilen Teminatlar & $866.200,00$ & $866.200,00$ \\
\hline $\begin{array}{l}\text { 3. Şüpheli Ticari } \\
\text { Alacaklar }\end{array}$ & $1.909 .350,06$ & 0,00 \\
\hline C. Diğer Alacaklar & $12.383,00$ & $12.383,00$ \\
\hline 1. Diğer Alacaklar & $12.383,00$ & $12.383,00$ \\
\hline D. Stoklar & $1.523 .898,32$ & $1.523 .898,32$ \\
\hline $\begin{array}{l}\text { 1. Verilen Sipariş } \\
\text { Avansları }\end{array}$ & $1.523 .898,32$ & $1.523 .898,32$ \\
\hline E. Diğer Dönen Varlıklar & $555.832,45$ & $555.832,45$ \\
\hline $\begin{array}{l}\text { 1. Peşin Ödenen } \\
\text { Vergiler }\end{array}$ & $265.225,35$ & $265.225,35$ \\
\hline 2. İş Avansları & $290.607,10$ & $290.607,10$ \\
\hline II. Duran Varlıklar & $4.671 .543,04$ & $8.432 .958,60$ \\
\hline A. Ticari Alacaklar & $2.257 .000,00$ & $2.257 .000,00$ \\
\hline 3. Alıcilar & $2.257 .000,00$ & $2.257 .000,00$ \\
\hline B. Maddi Duran Varlıklar & $1.517 .685,03$ & $5.060 .310,44$ \\
\hline 1. Makine ve Tesisatlar & $156.425,71$ & $314.476,00$ \\
\hline 2. Taşıtlar & $3.391 .457,85$ & $4.703 .018,94$ \\
\hline 3. Demirbaşlar & $52.203,93$ & $42.815,50$ \\
\hline $\begin{array}{l}\text { 4. Birikmiş } \\
\text { Amortismanlar }\end{array}$ & $2.082 .402,46$ & 0,00 \\
\hline $\begin{array}{l}\text { C. Maddi Olmayan Duran } \\
\text { Varlıklar }\end{array}$ & $896.858,01$ & $1.115 .648,16$ \\
\hline 1. Haklar & $1.121 .026,25$ & $1.115 .648,16$ \\
\hline $\begin{array}{l}\text { 2. Kuruluş-Örgütlenme } \\
\text { Giderleri }\end{array}$ & $1.831,07$ & 0.00 \\
\hline 3. Birikmiş Amortismanlar & $-225.999,31$ & 0.00 \\
\hline
\end{tabular}


Tablo 2. XYZ Şirketinin Ara Bilançosu ve Borca Batıklığa Esas Bilançosu (Pasifler)

\begin{tabular}{|c|c|c|}
\hline & Ara Bilanco & $\begin{array}{c}\text { Borç Batıklık } \\
\text { Bilançosu }\end{array}$ \\
\hline Pasifler & Kayıtlı Değer & Rayiç Değer \\
\hline \multicolumn{3}{|l|}{ I. Kısa Vadeli Borçlar } \\
\hline A. Mali Borçlar & $1.707 .028,52$ & $1.707 .028,52$ \\
\hline 1. Banka Kredileri & $1.707 .028,52$ & $1.707 .028,52$ \\
\hline B. Ticari Borçlar & $7.003 .513,97$ & 7.003.513,97 \\
\hline 1. Saticilar & $441.751,06$ & $441.751,06$ \\
\hline 2. Diğer Ticari Borçlar & $6.561 .762,91$ & $6.561 .762,91$ \\
\hline C. Diğer Borçlar & $124.886,66$ & $124.886,66$ \\
\hline 1. Personele Borçlar & $95.972,66$ & $95.972,66$ \\
\hline 2. Diğer Çeşitli Borçlar & $28.914,00$ & $28.914,00$ \\
\hline D. Alınan Avanslar & $39.040,00$ & $39.040,00$ \\
\hline 1. Sipariş Avansları & $39.040,00$ & $39.040,00$ \\
\hline $\begin{array}{l}\text { E. Ödenecek Vergi ve } \\
\text { Yükümlülükler }\end{array}$ & $378.783,70$ & $384.283,70$ \\
\hline $\begin{array}{l}\text { 1. Ödenecek Vergi ve } \\
\text { Fonlar }\end{array}$ & $333.532,71$ & $333.532,71$ \\
\hline $\begin{array}{l}\text { 2. Ödenecek SGK } \\
\text { Kesintileri }\end{array}$ & $45.250,99$ & $45.250,99$ \\
\hline $\begin{array}{l}\text { 3. Vadesi Geçmiş } \\
\text { Ertelen. veya Tak. } \\
\text { Ver. ve Diğ. Yük. }\end{array}$ & - & $5.500,00$ \\
\hline $\begin{array}{l}\text { Kisa Vadeli Yabanc1 Kay. } \\
\text { Toplamı }\end{array}$ & $9.253 .252,85$ & $9.253 .252,85$ \\
\hline II. Uzun Vadeli Kaynaklar & - & - \\
\hline A. Mali Mali Borçlar & $1.972 .871,34$ & $1.972 .871,34$ \\
\hline 1. Banka Kredileri & $1.035 .274,17$ & $1.035 .274,17$ \\
\hline $\begin{array}{l}\text { 2. Finansal Kiralama } \\
\text { Borçları }\end{array}$ & $1.140 .286,38$ & $1.140 .286,38$ \\
\hline $\begin{array}{l}\text { 3. Ertelenmiş Finansal } \\
\text { Kira. Borçları (-) }\end{array}$ & $202.689,214$ & $202.689,214$ \\
\hline B. Ticari Borçlar & $862.501,55$ & $862.501,55$ \\
\hline 1. Satıcilar & $366.000,00$ & $366.000,00$ \\
\hline 2. Diğer Ticari Borçlar & $496.501,55$ & $496.501,55$ \\
\hline $\begin{array}{l}\text { Uzun Vadeli Kaynak } \\
\text { Toplamı }\end{array}$ & $2.835 .372,89$ & $2.835 .372,89$ \\
\hline III. Öz Kaynaklar & & \\
\hline A. Ödenmiş Sermaye & $244.000,00$ & - \\
\hline B. Geçmiş Yıllar Karı & $946.030,41$ & - \\
\hline C. Dönem Net Karı (Zararı) & $-2.622 .094,41$ & - \\
\hline Öz Kaynaklar Toplamı & $-1.432 .064,00$ & - \\
\hline Pasif Kaynaklar Toplamı & $10.656 .561,74$ & $12.094 .125,74$ \\
\hline
\end{tabular}

Tablo 3. Karşılaştırmalı Olarak Borca Batıklık Oranının Hesaplanmas1

\begin{tabular}{cc}
\hline $\begin{array}{l}\text { Ara Bilanço'ya göre Borca } \\
\text { Batıklık Hesaplamas1 }\end{array}$ & $\begin{array}{l}\text { Güncellenmiş Bilanço’ya } \\
\text { göre Borca Batıklık } \\
\text { Hesaplamas1 }\end{array}$ \\
\hline $\begin{array}{c}10.656 .561,74-12.088 .625,74 \\
=-1.432 .064,00\end{array}$ & $12.508 .627,24-$ \\
(Negatif) & $12.094 .125,74=414.501,50$ \\
(Pozitif)
\end{tabular}

Borca Batıklık Oranı $=\% 88$

Borca Batıklık Oran $1=$ $\% 103,4$

Örneğimizde şirket ara bilanço üzerinden borca batıklık durumu negatif ve borca batıklık oranı 0,88 olması nedeniyle teknik olarak borca batık olduğu görülür. Güncellenmiş bilançoya göre ise borca batıklık, pozitif ve borca batıklık oranı 1,03 olması nedeniyle borçlu şirketin borca batı olmadığı sonucuna varılır. Bu bağlamda davacının borca batık olmadığının saptanması halinde, artık iyileştirme projesi irdelenemez. Böyle bir durumda davanın reddine karar verilmelidir (Aydemir, 2013).

\subsubsection{Borca Batıklk Durumunun Mahkemeye Bildirilmesi}

İflasın ertelenmesi borca batıklık halinde söz konusu olabileceğine göre iflasın ertelenmesinin söz konusu olabilmesi için, öncelikle ortada bir iflas hali yaratacak bir borca batıklık durumunun mevcut olması ve bu durumun da mahkemeye bildirilmesi gerekir. Nitekim iflasin ertelenmesinin düzenlendiği gerek TTK'nın 376. maddesi gerekse de İIK'nin 179. madde hükmü, şirketin borca batıklı durumunun mahkemeye bildirilmesinin gerekliliğine işaret etmektedir (Seyfi, 2007; Arzova, Yavaş ve Küçük, 2016).

Borca batıklık bildirimi sermaye şirketinin veya kooperatifin yeterli sermayesi bulunmaksızın ekonomik ilişkilerini devam ettirmesine ve böylece üçüncü kişilerin zarara uğratılmasına engel olacağından, sermaye şirketinin veya kooperatifin mevcut alacaklarını koruduğu gibi, sermaye şirketinin veya kooperatifin gelecek dönemlerindeki alacaklılarını ve kamuyu da muhafaza eder (Işık, 2010).

\subsubsection{Borçlunun Mali Durumunun İileştirilmesi Ümidinin Bulunmasl}

Bir işletmenin ekonomik durumu yönünden iyileştirme kavramı, o işletmenin içinde bulunduğu likidite noksanlığı veya borca batıklık durumunu aşmak ve bununla beraber işletmenin karlılığını tekrardan elde etme amacına ilişkin olan, gereken tüm mali ve yapısal tedbirlerin alınmasını ifade eder (Akdeniz ve Kayıhan, 2014).

İyileştirmede amaç, sermaye şirketi veya kooperatifin borca batıklığını gidererek işletmenin tüzel kişiliğinin devamlılığını, karlılığını ve erteleme kararının verildiği zamana oranla işletmenin mali durumunun daha iyi bir hale getirilmesinin sağlanmasıdır (Dumlupınar, 2014).

İflasın ertelenmesinin mahkemece kabul edilebilmesi için; sermaye şirketi/kooperatifin borca batık bir halde olması ve mali durumu iyileştirme ümidinin ve kurtarılmasının mümkün olması gerekir (Küçüköner, 2012). Çünkü İcra ve İflas Kanunu'nda, iyileştirme ümidi iflas ertelemesinin zorunlu bir koşulu olarak belirmektedir (İIK, 2004). İflasın ertelenmesi kurumu borca batmış olan her sermaye şirketi/kooperatif için değil, iyileşme ümidi mümkün olan sermaye şirketi/kooperatif için getirilmiş bir düzenlemedir (Güngör, 2016).

\subsubsection{Alacaklıların Durumu Iflasın Açılmasına Oranla Daha Kötü Bir Duruma Sokulmaması}

İflasın ertelenmesi müessesesi öncelikle şirketin menfaatleri göz önünde bulundurularak düzenlenmiş olmasına rağmen alacaklının kanunen korunan menfaatleri veya alacaklılar için sağlanan garantilerin ihlali söz konusu olmamalıdır (Erkek, 2013). 
İflasın ertelenmesi müessesesinin düzenlendiği gerek Türk Ticaret Kanunu'nun 376 ve 377. maddesinde gerekse de İcra ve İflas Kanunu'nun 179. maddesinde kanun koyucu alacaklıların mevcut durumunun iflasın açılmasına oranla daha kötü bir duruma sokulmaması şeklinde bir koşul aramamıştır (Seyfi, 2007). Ama Yargıtay 19. Hukuk Dairesi bir kararında “... alacaklıların da menfaatleri kuşkusuz korunmalıdır" şeklinde ifade etmiştir (Y1lmaz, 2009).

\subsubsection{Iflasin Ertelenmesinin Talep Edilmesi}

Borca batmış bir halde olan sermaye şirketinin iflasının ertelenmesine karar verilebilmesi için, ilk önce yetkili ticaret mahkemesine iflasin ertelenmesine dair bir talepte bulunulması gerekir. Aksi takdirde yetkili ticaret mahkemesi, iflasın ertelenmesi talebini re'sen alabileceği bir karar değildir (Yıldız, 2016; Alptürk ve Bostancıoğlu, 2011; Oy, 2009).

Íflasın ertelenmesi talebi, hem idare ve temsille vazifelendirilmiş kimseler hem de alacaklılar bakımından isteğe bağlı bir taleptir. Ancak iflasın ertelenebilmesi için varlığı zorunlu olan şartlardan biridir (Dumlupınar, 2014; Arzova vd., 2016). Bu bağlamda talep olmadan iflasın ertelenmesi kararı verilemez.

\subsubsection{Iyileştirme Projesinin Mahkemeye Sunulması}

Mahkeme, sermaye şirketinin mali durumunun iyileştirilmesi ümidinin var olup olmadığı hakkında bir kanıya varabilmesi için (Musaballı, 2005) iflasın ertelenmesi talebi ile beraber mahkemeye iyileştirme projesini de sunmak zorundadır (Alptürk ve Bostancıŏlu, 2011; Börü, 2016). İflasın ertelenmesi için gerekli olan bu zorunluluk TTK'nın 377. maddesinde ve İİK'nun 179. maddesinde ifade edilmektedir.

\subsubsection{Fevkalade Mühletten Yararlanılmamış Olması}

Sermaye şirketi iflâsın ertelenmesi müessesesinden yararlanabilmesi için ayrıca fevkalade süreden de yararlanmamış olması gerekir (Dumlupınar, 2014). Yani iflas erteleme talebinin diğer bir sinırlaması sermaye şirketinin fevkalade mühlet elde etmiş olmasıdır (Öztek, 2006).

Nitekim Yargıtay 19. Hukuk Dairesi'nin verdiği bir kararda; "İflasın ertelenmesi için erteleme talebinde bulunan şirketin ... fevkalade mühletten (İIK, 2004) yararlanmamış olması gerekir" (Milanlığlu, 2014) ifadelerine yer verilmiştir.

\subsubsection{Iflasin Erteleme Masraflarinin Mahkeme Veznesine Depo Edilmesi}

Kanunda açıkça düzenlenmemekle birlikte doktrinde iflasın ertelenmesi şartlarından bir diğeri de başta iflasın ertelenme kararının ilanı ve bildirimi masrafı, bilirkişi masrafları, atanması durumunda kayyım ücreti ve mahkeme tarafından alınacak diğer tedbirlerin uygulanabilmesi için gerekli masraflar, iflas erteleme talebinde bulunanlar tarafindan peşin olarak mahkeme veznesine depo edilmesidir (Yıldız, 2016; Özekes, 2007; Uzay, 2008; Musaball1, 2005). Bunun için İIK'nun 181. maddesinde masrafların peşin ödenmesine ilişkin İIK'nun 160. maddesine yapılan atıf da göz önünde tutulur (Akdeniz ve Kayıhan, 2014).

\subsubsection{1. Şirketin veya Kooperatifin Mahkemece Iflasin Ertelenmesine Layık Görülmesi}

İflasın ertelenmesi şartlarına, 09.08.2016 tarihinde Resmi Gazete'de yayınlanarak yürürlüğe giren 6728 sayılı Yatırım Ortamının İyileştirilmesi Amacıyla Bazı Kanunlarda Değişiklik Yapılmasına Dair Kanun ile İIKK'nun 179. maddesinde yapılan değişiklikle yeni bir şart eklenmiştir. Bu şart iflas erteleme yargılaması sonucunda mahkeme tarafından şirket veya kooperatifi iflas ertelemeye layık görmesi durumudur.

Yapılan bu değişiklik İİK'nun 179/a maddesinin son fikrasında düzenlenmiştir. Bu maddeye göre: "Mahkeme, projeyi ciddi ve inandirlc bulur ve şirket veya kooperatifi iflasın ertelenmesine layı görürse iflasın ertelenmesine; şirket veya kooperatifin borca batık olmadığını tespit ederse erteleme talebi ile iflas davasının reddine; aksi takdirde şirketin veya kooperatifin iflasına karar verir" şeklinde ifade edilmiştir.

\section{2. İflasın Ertelenme Süresi}

İIK 179/b maddesince iflas erteleme süresi 1 yildır. Bu 1 yıllık süre kayyım veya kayyım heyetinin verdiği raporlar doğrultusunda 1 yıl daha uzatılabilmektedir. Eğer alacaklıların haklarının korunduğu ve işletme faaliyetlerinin mahkemeye sunulan proje kapsamında pozitif bir şekilde yürüdüğü kanaati mevcutsa bu süre uzatılabilir. Aksi takdirde, şirketin mali yapısının iyileşmemesi hatta daha da kötüye gitmesi ve alacaklılara hakkaniyet çerçevesinde yaklaşılmaması durumunda, şirketin veya kooperatifin mahkemece iflasına karar verilebilir (Varıc1, 2014). Bu bağlamda iflasın ertelenmesinin toplam süresi iki yılı geçememektedir.

İflasın ertelenmesi süresinin sonunda iki ihtimal ile karşılaşılır (Kuru, 2006):

(i) Şirketin veya kooperatifin mali durumu düzelmiştir, yani aktifi borçlarını karşılayacak duruma gelmiştir. $\mathrm{Bu}$ halde, mahkemenin iflasın ertelenmesi kararını kaldırması gerekir. Bununla şirket veya kooperatif tekrar normal durumuna kavuşmuş olur.

(ii) Şirketin veya kooperatifin mal durumu düzelmemiştir ve düzelmesi ihtimali de olmadığından, iflasın ertelenmesi süresini uzatmakta da bir fayda görülmemektedir. $\mathrm{Bu}$ halde, ticaret mahkemesi şirketin veya kooperatifin iflasına karar verir ve şirket veya kooperatif iflas hükümlerine göre tasfiye edilir.

\section{3. İflasın Ertelenme Süreci}

Hukuk sistemimizde iflas erteleme müessesesinin işleyişinin büyük bir payı İcra ve İflas Kanunu'nun ilgili maddeleri ile düzenlenmiş olmakla beraber, açık olmayan hususlar Yargitay kararları ile tamamlanmıştır. Íflasın ertelenmesi müessesesi, borca batık olma durumunun ortaya çıkması ile başlayan ve nihayetinde iyileşme veya iflasla sonlanan, içinde birçok ayrıntıyı içeren bir süreçtir (Uzay, 2008; Toplu, 2016). Söz konusu süreç aşağıdaki şekildeki gibi özetlenebilir; 
Şekil 1. İflas Erteleme Süreci Aşamaları
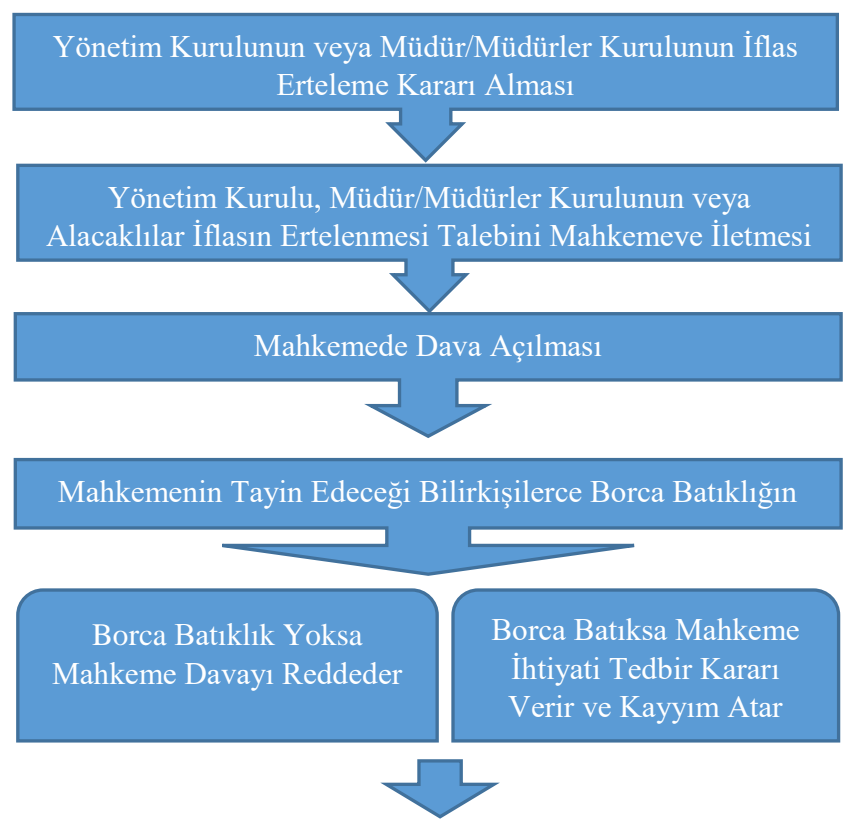

İhtiyati Tedbir Kararının 3. Kişilere İlan Edilmesi ve 3.

Kişilerin Yasal Sürede İtiraz Etmesi ve Mahkemece İlgili İtirazların Değerlendirilmesi

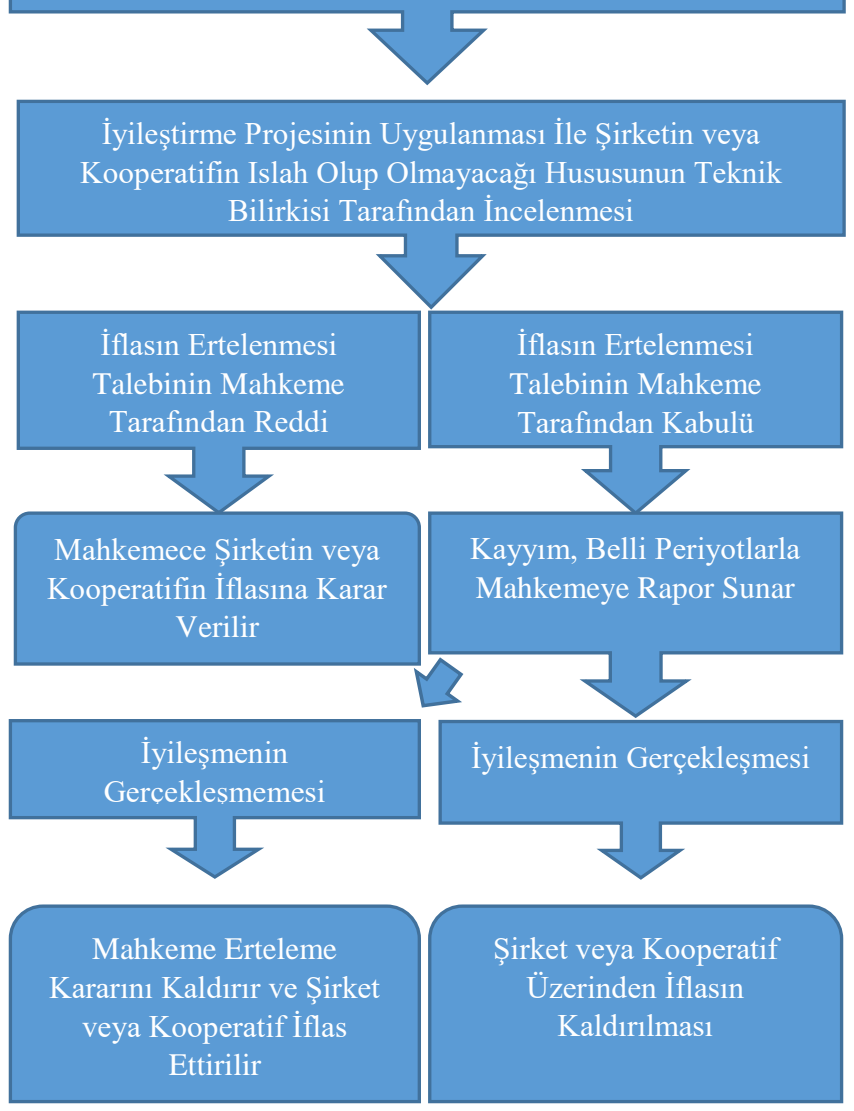

\section{Uygulama}

İnşaat sektöründe, inşaat malzemeleri üretimi ve satışıyla uğraşan ABC İnşaat ve Ticaret Anonim Şirketi'nin, ülke ve faaliyette bulunduğu bölgede yaşanan ekonomik gelişmeler şirketi olumsuz etkilemiş ve yaşanan sıkıntılar, şirketin mali yapısının bozulmasına neden olmuştur. $\mathrm{Bu}$ nedenle alacaklarını zamanında tahsil edememesi ve yeni yatırımlarının finansmanı için bankalardan sağladığı kredi geri ödemelerinde sorunlar yaşaması nedeniyle borca batık hale geldiğini ve sunulan iyileştirme projesiyle kısa sürede durumunu düzeltebileceği gerekçesiyle borca batıklığa dayalı olarak iflas erteleme davası açtığını ve mahkemece yaptırılan bilirkişi incelemesi sonunda, bilirkişi kurulunca aşağıdaki şekilde bir bilanço hazırlanmıştır.

Tablo 4. ABC Şirketinin Ara Bilançosu ve Borca Batıklığa Esas Bilançosu (Aktifler)

\begin{tabular}{|c|c|c|}
\hline & $\begin{array}{c}\text { Ara } \\
\text { Bilanco }\end{array}$ & $\begin{array}{c}\text { Borç } \\
\text { Batıklık } \\
\text { Bilançosu }\end{array}$ \\
\hline Aktif(Varlıklar) & $\begin{array}{l}\text { Kayitl1 } \\
\text { Değer }\end{array}$ & Rayiç Değer \\
\hline I. Dönem Varlıklar & 6.000 .000 & 5.500 .000 \\
\hline A. Hazır Değerler & 200.000 & 200.000 \\
\hline 1. Kasa & 5.000 & 5.000 \\
\hline 2. Alınan Çekler & 195.000 & 195.000 \\
\hline C. Ticari Alacaklar & 1.500 .000 & 1.500 .000 \\
\hline 1. Alıcilar & 1.500 .000 & 1.500 .000 \\
\hline E. Stoklar & 3.500 .000 & 3.500 .000 \\
\hline 1. İlk Madde ve Malzeme & 1.000 .000 & 750.000 \\
\hline 2. Ticari Mallar & 3.000 .000 & 2.750 .000 \\
\hline $\begin{array}{l}\text { 3. Stok Değer Düşük } \\
\text { Karşıllığ (-) }\end{array}$ & $(500.000)$ & - \\
\hline $\begin{array}{l}\text { G. Gelecek Aylara Ait Girdiler } \\
\text { ve Gelir Tahakkukları }\end{array}$ & 300.000 & - \\
\hline $\begin{array}{l}\text { 1. Gelecek Aylara Ait } \\
\text { Girdiler }\end{array}$ & 300.000 & - \\
\hline H. Diğer Dönen Varlıklar & 500.000 & 300.000 \\
\hline 1. Peşin Ödenen Vergiler & 100.000 & 100.000 \\
\hline 2. İş Avansları & 200.000 & 200.000 \\
\hline $\begin{array}{l}\text { 3. Sayım ve Tesellüm } \\
\text { Noksanları }\end{array}$ & 200.000 & - \\
\hline II. Duran Varlıklar & 15.000 .000 & 8.250 .000 \\
\hline D. Maddi Duran Varlıklar & 7.000 .000 & 6.250 .000 \\
\hline 1. Arsa ve Araziler & 700.000 & 1.000 .000 \\
\hline 2. Makine ve Cihazlar & 5.875 .000 & 4.000 .000 \\
\hline 3. Taşıtlar & 1.125 .000 & 1.250 .000 \\
\hline $\begin{array}{l}\text { 4. Birikmiş Amortismanlar } \\
(-)\end{array}$ & $(700.000)$ & - \\
\hline $\begin{array}{l}\text { E. Maddi Olmayan Duran } \\
\text { Varlıklar }\end{array}$ & 8.000 .000 & 2.000 .000 \\
\hline 1. Haklar & 2.000 .000 & 2.000 .000 \\
\hline 2. Şerefiyeler & 3.000 .000 & - \\
\hline 3. Özel Maliyetler & 3.500 .000 & - \\
\hline $\begin{array}{l}\text { 4. Birikmiş̧ Amortismanlar } \\
(-)\end{array}$ & $(500.000)$ & - \\
\hline Aktif (Varlıklar) Toplamı & 21.000 .000 & 13.750 .000 \\
\hline
\end{tabular}

Tablo 5. ABC Şirketinin Ara Bilançosu ve Borca Batıklığa Esas Bilançosu (Pasifler)

\begin{tabular}{lcr}
\hline & $\begin{array}{c}\text { Ara } \\
\text { Bilanco }\end{array}$ & $\begin{array}{c}\text { Borç } \\
\text { Batıklık } \\
\text { Bilançosu }\end{array}$ \\
\hline Pasif (Kaynaklar) & $\begin{array}{c}\text { Kayıtlı } \\
\text { Değer }\end{array}$ & Rayiç Değer \\
\hline III. Kısa Vadeli Yabancı & 18.500 .000 & 18.500 .000 \\
$\quad$ Kaynaklar & 7.500 .000 & 7.500 .000 \\
A. Mali Borçlar & 7.500 .000 & 7.500 .000 \\
1. Banka Kredileri & 2.500 .000 & 2.500 .000 \\
B. Ticari Borçlar & 2.500 .000 & 2.500 .000 \\
1. Satıcılar & &
\end{tabular}




$\begin{array}{lrr}\text { C. Diğer Borçlar } & 7.000 .000 & 7.000 .000 \\ \text { 1. Ortaklara Borçlar } & 5.000 .000 & 5.000 .000 \\ \text { 2. Personele Borçlar } & 2.000 .000 & 2.000 .000 \\ \text { F. Ödenecek Vergi ve Diğer } & 1.500 .000 & 1.500 .000 \\ \quad \begin{array}{l}\text { Yükümlülükler } \\ \text { 1. Ödenecek Vergi ve Fonlar }\end{array} & 1.300 .000 & 1.300 .000 \\ \text { 2. Ödenecek Sosyal } & 200.000 & 200.000 \\ \quad \text { Güvenlik Kesintileri } & & \end{array}$

IV. Duran Varlıklar

$\begin{array}{lr}\text { V. Öz Kaynaklar } & 2.500 .000 \\ \text { A. Ödenmiş Sermaye } & 2.500 .000 \\ \text { 1. Sermaye } & 2.500 .000 \\ \text { B. Kar Yedekleri } & 100.000 \\ \text { 1. Özel Fonlar } & 100.000 \\ \text { C. Geçmiş Yıl Zararları (-) } & (100.000) \\ \text { 1. Geçmiş Y1l Zararları (-) } & 100.000\end{array}$

Pasif (Kaynaklar) Toplamı

$21.000 .000 \quad 18.500 .000$

Dönen Varliklar:

5.500.000 TL

Duran Varlıklar:

8.250.000 TL

Mevcut+Alacak Toplamı:

$13.750 .000 \mathrm{TL}$

Kisa Vadeli Yabancı Kaynaklar:

Uzun Vadeli Yabancı Kaynaklar:

Yabancı Kaynaklar Toplamı

18.500.000 TL

$0 \mathrm{TL}$

18.500.000 TL

Bilançodan görüleceği üzere şirketin mevcut ve alacakları toplamı 13.750.000 TL ve yabanc1 kaynaklar (borçlar) toplamı ise 18.500.000 TL'dir. Bu durum, şirketin toplam borçlarının toplam varlıklarını 4.750.000 TL (18.500.00013.750.000) aştığ 1 ve borca batıklık oranının 0,74 yani negatif olduğu, dolayısıyla şirketin BORCA BATIK olduğunu göstermektedir.

\subsection{ABC İnşaat ve Ticaret Anonim Şirketi'nin İyileştirme Projesi}

Firma çözüm projeleri olarak aşağıdaki önerilerde bulunmuştur:

(i) Firmanın hali hazırda mevcut 2 hizmet alım sözleşmesi mevcuttur. Bu hizmet alım ihalelerinden elde edilecek kar payları çözüm projesinin esasını oluşturmaktadır.

Tablo 6. ABC Firmasının 2 Hizmet Alımı Sözleşme Bedeli

\begin{tabular}{llccc}
\hline SR & \multicolumn{1}{c}{ İşin Adı } & $\begin{array}{c}\text { Yüklenici } \\
\text { Firma }\end{array}$ & $\begin{array}{c}\text { Sözleşme } \\
\text { Tarihi }\end{array}$ & $\begin{array}{c}\text { Sözleşme } \\
\text { Bedeli }\end{array}$ \\
\hline 1 & X Hastanesi & ABC A.Ş & $25 / 08 / 201^{*}$ & 4.250 .000 \\
& Yapım İşi & & & TL \\
2 & Y Karayolu & ABC A.Ş & $30 / 10 / 201 *$ & 2.500 .000 \\
& Bakım Onarım & & & TL \\
& İşi & & & \\
\hline
\end{tabular}

(ii) Firma kendi ortakları ve yan kuruluşlardan maddi menfaatler sağlayacaktır.

(iii) Firma adına kayıtlı bulunan gayrimenkuller değerlendirilecek ve katkı sağlanacaktır.

(iv) Firmanın alacaklı olduğu icra dosyalarından tahsil edilecek alacaklar da alacaklılara dağıtılacaktır.

(v) Zorunlu giderler dışındaki giderlerde azaltılacaktır. (vi) İcra takibine konu olmamış ancak tahsil edilmemiş alacaklar tahsil edilecektir.

Yukarıda sayılan hususlar gerçekleştirildiğinde, firmanın faaliyetlerini sürdürme imkânına kavuşması, ekonomiye katkı sağlayacağı ve borçlarını ödeyerek alacaklıların mağduriyetinin giderilmesi sağlanacaktır.

\subsection{Mahkeme ve Bilirkişi Heyetinin Çalışmaları}

ABC İnşaat ve Ticaret Anonim Şirketi'nin avukatı Bay A, 15/01/201x tarihinde yukarıda özetlenen iyileştirme projesi ve ara bilançonun da bulunduğu dava dosyası ile Van 1. Asliye Mahkemesi'ne iflas erteleme talebiyle dava başvurusunda bulunmuştur. Dava hâkimi, dosyayı inceledikten sonra 5 kişilik bir bilirkişi heyeti atamıştır. $\mathrm{Bu}$ bilirkişi heyetinde, alanlarında uzman makine mühendisi, inşaat mühendisi, yeminli mali müşavir, finans ve hukuk uzmanı yer almaktadır. 17/01/201x tarihinde Dava hâkimi yanında bilirkişi heyeti bulunmak suretiyle ABC İnşaat ve Ticaret Anonim Şirketi'ne keşifte bulunmuşlardır.

Keşif anında gerekli araştırmalar yapılmış ve firma yetkilisi ile görüşülmüştür. Keşif tutanağı tutulduktan sonra Dava hâkimi, bilirkişi heyetindeki uzmanlara görevlerini tevdi etmiş ve ivedilikle (1 hafta içinde) Bilirkişi Raporu'nun düzenlenmesini istemiştir.

Bilirkişi heyetinden Makine Mühendisi Bay E, ABC şirketinin Duran Varlıklarının rayiç bedellerinin tespitini; İnşaat Mühendisi Bayan $\mathrm{C}, \mathrm{ABC}$ şirketinin Stoklarının rayiç bedellerinin tespitini; bilirkişi heyetinden Yeminli Mali Müşavir Bay F ve Finans Uzmanı Bay X, ABC şirketini ziyaret ederek, yasal defterlerini kontrol etmiş ve firmanın hazırladığ 1 ara bilanço ile bilirkişi heyetinin çalışmaları sonucunda tespit edilen değerlere göre yukarıdaki Borca Batıklık Bilançosunu düzenlemişlerdir.

Bilirkişi heyetinden hukuk uzmanı Bayan $\mathrm{C}$, heyet üyelerinin yaptıkları çalışmaları derledikten sonra Mahkeme Heyeti'ne sunulacak olan Bilirkişi Raporu'nu düzenlemiş ve sonuç kısmını şöyle özetlemiştir:

Davacı vekilinin 15/01/201x tarihli dava dilekçesi ve eki evrak ile dosya münderecatında yer alan şirket kayıtlarına göre; kayıtlı değerlere göre aktiflerin, finansal yönden pasifleri karşılayamadiğ ve bu durumun ise davacı şirketin borca batık olduğuna delalet ettiğ $i$;

Iyileştirme projesine göre şirketin daha önceden yapılan hizmet alımlarından ve mevcut işlerden elde edilecek kazançların, şirketi negatif durumdan çıkartarak pozitife geçmesinin temin edilebileceği,

Davacı şirketin daha önceki yıllarda yapmış olduğu hizmet alımlarına göre piyasada iş yapabilen bir firma olduğu, önemli ölçüde personel istihdam ettiği;

Şirketin iflasina karar verilmesi durumunda işletmeye dâhil olan unsurların parçalanarak satışlarından elde edilecek hasılatın, mevcut borçlara, isleyecek faizler de dikkate alındı ̆̆ında alacaklıların tüm alacaklarını karşılamaya yetmeyeceği;

IIK md.179 uyarınca iflası ve fakat şirketin mali durumunun iyileştirmesi ihtimalinin varlığından söz 
edilerek iflasinın ertelenmesi talep edilen davacı şirketin mali durumunun borca batık hale düşmüş olduğu;

Iyileştirme projesi ve eklerinde yer alan sözleşmelerin gözetilerek davacı şirketin faaliyetini sürdürmesine imkân sağlanması halinde davacı şirketin 1 yıl daha erteleme süresi içinde borca batık durumundan kurtulabileceği yolunda görüş oluşmuştur.

Takdiri yüce mahkemeye ait olmak üzere gereğini sayglyla sunarı.

\section{Sonuç}

Ticari hayat, getirdiği kazanımlarla birlikte bir takım riskleri de bünyesinde barındırmaktadır. Bilindiği üzere ticari faaliyette bulunan müteşebbislerin temel amacı kar elde etmektir. Ancak zaman zaman bu amaçlarına ulaşmak bir yana mevcudu da korumayarak zarar da edebilmektedirler. $\mathrm{Bu}$ zararlarını zamanla kapatamayan tacirler ciddi borç yükleriyle muhatap olmakta ve borca batık duruma gelmektedirler. Alacaklarına karşı sorumluluklarını yerine getiremeyen bu tacirler iflasla karşı karşıya kalabilmektedirler.

Sermaye şirketlerinde ortaklar, şirketin kendi borçlarından dolayı şahsi malvarlıkları ile sorumlu olmadıkları, şirket alacaklıları alacaklarını tahsil için sadece borçlu şirketin malvarlığına başvurabildikleri için, borca batıklık hukuken doğrudan doğruya iflas nedenidir. Ancak, bir işletmenin var olmasının çeşitli menfaat gruplarını ilgilendirmesinden dolayı Kanun Koyucu işletmelerin hayatiyetlerinin sona ermesi yerine sürdürülmesi amacıyla düzenlemeler yapmıştır (Yılmaz, 2009). Yapılan bu düzenlemelerden biri TTK'nın 377. maddesi, İİK'nun 179. maddesi ve Kooperatifler Kanunu'nun 63. maddesinde yer alan iflasin ertelenmesi müessesesidir.

İflasın ertelenmesi talebinin gündeme gelebilmesin en önemli koşulu sermaye şirketinin borca batık bir durumda bulunup bulunmadığıdır. Sermaye şirketi borca batık bir durumda değilse mahkemece iflasın ertelenmesi kararının verilmesi mümkün olmayacaktır. Borca batık olma halinin anlaşılması borca batıklık bilançosundan ortaya çıkacaktır. Borca batıklık bilançosunun aktif tarafında, bilançonun düzenlendiği tarihteki muhtemel satış değerleri yer almalı; pasif tarafında ise, yıllık bilançonun pasif tarafında yer alan tüm kalemler değil, ödenmesi gereken gerçek şirket borçlarına yer verilmelidir (Küçük, 2011). Bunun yanında bir diğer önemli şart işletmenin mali durumunun iyileşme ümidini gösteren ciddi ve inandırıcı bir iyileştirme projesinin sunulmasidir. Erteleme talebinde bulunan taraf, erteleme talebiyle birlikte iyileştirme projesinin yanında gerekli olan her türlü bilgi ve belgeyi mahkemeye sunmalıdır. Bunun dışında iflasın ertelenmesi için yapılan veya yapılacak masraflar da mahkeme veznesine depo edilmelidir.

Mahkeme, iflâsın ertelenmesi kararı ile birlikte borçlu şirketin malvarlığını korumak için gerekli tedbirler alır ve bunun yanında borçlu şirketin veya kooperatifin malvarlığını idare etmek ve borçlunun işlemlerini kontrol etmek için yönetim kayyımı veya denetim kayyımı atar (Ermenek, 2008).
Toplamda 2 yllı geçemeyen iflasın ertelenme süresi, 1 yılı iflas erteleme kararının verilmesiyle, 1 yılı ise iflas erteleme kararının uzatılmasıyla oluşur. $\mathrm{Bu}$ süreç içerisinde şirket veya kooperatif, iyileştirme projesinde sunmuş olduğu iyileştirmeye yönelik tedbirleri kayyım gözetim ve denetiminde uygular. Şayet iflas erteleme süresince şirketin borca batıklığ giderilemediği takdirde mahkeme, şirketin veya kooperatifin iflasına karar vererek, şirket veya kooperatif iflas masasına devredilir. Fakat uygulanan projeler neticesinde şirketin veya kooperatifin borca batıklık durumu ortadan kalkarsa, mahkeme kayyım ve bilirkişilerden aldığı raporlar doğrultusunda şirket/kooperatif üzerindeki iflas erteleme kararını kaldırır ve şirket/kooperatif normal ticari faaliyetlerine devam eder (Şimşek, 2014).

Ticari hayatın istikrarı için çok faydalı olabilecek olan ve iyi niyetli şirketlerin kurtulmasına hizmet eden iflasın ertelenmesi müessesesi, kötü niyetli şirket/kooperatifler tarafından suiistimal edilen bir kurum haline gelmiştir. Fakat aslında sorun, iflas erteleme müessesinde değil, kurgulanan mekanizmadadır. $\mathrm{Bu}$ bağlamda iflasın ertelenmesi müessesenin kötüye kullanılmasının belli başlı bazı aksayan yönlerinin olmasıyla birlikte kanun boşluklarından yararlanmaya çalışan kötü niyetli mükelleflerin de hileli yöntemleri bulunmaktadır. Bunları kısaca özetlersek;

(i) Mahkemece atanan ve iflas erteleme süresince firma yönetiminde yer alan kayyımların, ilgili sektörün gerektirdiği mesleki bilgi, deneyim ve yeterliliğe sahip olmamaları,

(ii) Firmanın iflas erteleme talebine dayanak oluşturacak iyileştirme projesinin, yani borçlarından nasıl kurtulacağına ilişkin çıkış planının, gerçekçi ve uygulanabilir olup olmadığının yeterince ve gerektiği gibi değerlendirilmemesi,

(iii) Mahkeme tarafından atanan yerel bilirkişilerin uzmanlık ve yeterliklerine ilişkin zafiyetler,

(iv) Erteleme kararı almak amacıyla firmanın iş hacmi ve geçmiş performansıyla örtüşmeyen, şişirilmiş değerlerle hazırlanmış iyileştirme projeleri,

(v) İyileştirme projelerinde borç yapılandırmasını yapacaklarını belirten şirket veya kooperatiflerin borç yapılandırma anlamında herhangi bir girişimde bulunmamalar1,

(vi) Şirket veya kooperatifler, borca batık olduklarını göstermek için kendi şirketlerini birbirine borçlandırma olarak göstermeleri,

(vii)İflas erteleme kararını kullanan mükellefler şirketlerin içini boşaltmaları ve işletmeleri yeni şirketlere aktarmaları gibi iflasın ertelenmesinin suiistimal edilmesinin birçok şekli görülmektedir.

İşte tüm bu ortaya çıkan aksak yönleriyle beraber suiistimale açık olan iflasın ertelenmesi müessesesi 20 Temmuz 2016 tarihli, 9064 sayılı Bakanlar Kurulu Kararıyla ülke genelinde ilan edilen olağanüstü hal kararıyla OHAL süresi ile kısıtlı olmak üzere; iflasın ertelenmesi başvuruları ve tedbir hükümleri ile ilişsili yasak ve kısıtlamalar getirilmişti. Daha sonra 15.03.2018 tarih ve 7101 sayılı 7101 Sayılı ile iflas erteleme müessesesi yerine konkordato getirilmiştir. 
İIK'na göre Konkordato tanımı; borçların yeniden yapılandırılması suretiyle iflasa tabi borçluların mali durumunun düzeltilerek iflastan kurtulmasını, diğer borçluların ise mali durumunun düzeltilmesini amaçlayan, alacaklıların da belirli bir tenzilatla veya vadede alacağına kavuşmasını sağlayan ve mahkemenin tasdikiyle taraflar açısından bağlayıcı hale gelen bir anlaşmadır.

Şekil açısından değerlendirildiğinde; iflas erteleme, esas olarak bir borca batıklık bilançosunun ve bir iyileştirme projesinin varlığını gerektirir. Konkordato'da ise sadece usulüne uygun bir konkordato projesinin varlığını gerektirir. Konkordato herkese açık bir imkândır: sermaye şirketleri, gerçek kişi ticari işletmeleri, gerçek kişiler gibi. Oysa iflas erteleme sadece sermaye şirketlerinin ve kooperatiflerin başvurabileceği bir yoldur. Hem konkordato hem iflas erteleme, bir borçlunun mali durumunun düzeltilmesine imkân verebilir. Ancak; iflas erteleme, sadece borçları aktiflerinden fazla olan, borca batık olan borçlunun başvurabileceği bir yol iken, konkordato borç ödemeden aciz halde olan bir borçlunun da başvurabileceği yollardır.

Önceki düzenleme olan İflas ertelemede; bilirkişi ve kayyum kurumunun ön planda olma durumu varken, Konkordato'da alacaklılar ve kolektif olarak Alacaklilar Kurulunun karar alma, raporlama ve bir nevi denetim kabiliyetinin mevcudiyeti sebebiyle farklılıklar ve aktif rol almaları söz konusu olabilmiştir. Konkordatoda, alacaklılarında aktif rol alarak sisteme dâhil olması sayesinde daha saydam ve daha denetlenebilir bir süreç ortaya çıktığından eski düzenlemelerden daha doğru ve kesin sonuçlara, tüm taraflar açısından, ulaşılacağı söylenebilir (Atlı, 2018).

$\mathrm{Bu}$ çalışmada, Van ilinde iflas erteleme davasında bulunan bir firmanın bilgilerinden yararlanılarak iflas erteleme ve borca batıklık hakkında bilgi verilmiştir. İflas erteleme başvurusunda bulunan firmanın mahkemeye yapmış olduğu başvuru sonrasında borca batıklık bilançosu düzenlenmiş daha sonra bilirkişi heyetinin mahkemeye tevdi ettiği raporlarla firmanın borca batık olduğu tespit edilmiş ve bununla beraber mahkeme firmanın iflas erteleme talebini kabul etmiştir.

\section{Kaynakça}

Akdeniz, M., \& Kayıhan, Ş. (2014). Iflasın ertelenmesi ve hukuki sonuçlarl dava dilekçesi örneği ve yargitay kararları ekleri ile. İstanbul: Kabalcı Yayıncılık.

Alptürk, E., \& Bostancıŏ̆lu, E. (2011). Iflas ertelemesinin hukuksal ve vergisel boyutu. Lebib Yalkın Yayınları, LYY Mevzuat Dergisi, (Erişim: 07/01/2011), http://www.vmhk.org.tr/iflas-ertelemesinin-hukuksalve-vergisel-boyutu/.

Arslan, R. (2008). İflasın ertelenmesi uygulamaları. Bankacllar Dergisi, 116-123.

Arzova, S. B., Yavaş, M., \& Küçük, B. (2016). Hukuki ve mali yönden iflasin ertelenmesi ve borca batıklık bilançosu. Ankara: Seçkin Yayıncılık.

Aslanoğlu, S., Yavaşi, M., \& Özalp, A. R. (2014). Iflasın ertelenmesinde kamu alacaklarına sağlanan imtiyaz. Yaklaşım Dergisi, 253, Ocak 2014. (Erişim: 01/06/2017), www.turkhukuksitesi.com/makale_1762.htm/
Atalay, O. (2010). İflas sistemimiz neden iflas etti. Medeni Usül ve İcra-Íflas Hukukçuları Toplantısı VIII, Ankara: Türkiye Barolar Birliği Yayınları, 181-206.

Atlı, (2018). Iflasın yeni ertelenme şekli konkordato sözleşmesi. (Erişim: 12/06/2018), atli.av.tr/2018/04/27/ iflasin-yeni-ertelenme-sekli-konkordato-sozlesmesi/

Aydemir, E. (2013). Iflasın ertelenmesi ve kayyımlık. Ankara: Seçkin Yayıncılık.

Beylik, A. (2011). Iflasın ertelenmesinin hukuki boyutu. (Erişim: 19/12/2017), www.adaletbiz.com/iflasinertelenmesinin-hukuki-boyutu- makale128.html.

Bitlisli, F., \& Yılmaz, T. (2016). İflasın ertelenmesinde borca batıklık bilançosunun oluşturulması: bir uygulama. Mehmet Akif Ersoy Üniversitesi Sosyal Bilimler Enstitüsü Dergisi, 8(15), 207-223.

Börü, L. (2016). İflâsın ertelenmesinde iyileştirme projesinde öngörülen iyileştirme tedbirlerinin somutlaştırılması gerekliliği üzerine bazı değerlendirmeler. Ankara Barosu Dergisi, 1, 185-216.

Çetin, Ö. K. (2010). Iflâsın ertelenmesi bağlamında kayyımlık. Yüksek Lisans Tezi. Ankara: Ankara Üniversitesi.

Diril, M. (2014). Iflas erteleme nedir? hukuki ve mali sonuçları açısından iflas erteleme sürecinin incelenmesi. İzmir SMMMO.

Dumanoğlu, S. (2011). Iflasın ertelenmesi, borca batıklık ve iyileştirme projeleri. İstanbul: Beta Basım Yayım.

Erkek, C. Ü. (2013). İflasın ertelenmesinin şartları. Yüksek Lisans Tezi. İstanbul: İstanbul Üniversitesi.

Eroğlu, N. (2014). Iflasın ertelenmesi talebi üzerine alınabilecek tedbirler ve erteleme kararının sonuçları. Yüksek Lisans Tezi. Ankara: Başkent Üniversitesi.

Güçlü, M. (2016). İflâs ertelemesi: uygulamada yaşanan sorunlar ve çözüm önerileri. Bankacılar Dergisi, 96.

Güngör, M. (2016). Iflasın ertelenmesinde borca batıklık, rayiç değer tespiti ve iyileştirme projesi. Ankara: Seçkin Yayıncilik.

Işık, Z. (2010). Iflasın ertelenmesinin usul ve esasları. Yüksek Lisans Tezi. Kocaeli: Kocaeli Üniversitesi.

İIK (2004). Ícra ve Iflas Kanunu. (Erişim: 01/06/2017), http://www.mevzuat.gov.tr/MevzuatMetin/1.3.2004.pdf.

Kırtıloğlu, S. S. (2007). Iflas davast. Yüksek Lisans Tezi. Konya: Selçuk Üniversitesi.

Kuru, B. (2006). Pasifi aktifinden fazla olan sermaye şirketlerinin iflası. Medeni Usul Hukuku, İcra ve Iflas Hukuku ve Diğer Konular. İstanbul: Arıkan Yayınları.

Küçüköner, Ü. (2012). Iflas erteleme davalart. (Erişim: 25/12/2017), http://www.kucukoner.av.tr/ DOSYALAR/iflas_erteleme_davalari.pdf.

Milanlığlu, U. K. (2014). Iflas ertelenmesinde iyileștirme projeleri ve iyileştirme projelerinin özellikleri. Doktora Sunum Ödevi. İstanbul: Kadir Has Üniversitesi. 
Musaball1, A. (2005). Iflasin ertelenmesi şartlart. (Erişim:25/12/2017), http://www.turkhukuksitesi.com/ makale_240.htm.

Oy, O. (2009). İflasın ertelenmesi. İstanbul: Beta Basım Yayım.

Özalp, A. R. (2013). Iflasin ertelenmesi etkilerinin değerlendirilmesi. (Erişim: 14/12/2017), http://www. musbarosu.org.tr/Detay.aspx?ID=20438\&Tip=Haber,\% 20Tarih:\%2016.09.2013.

Özekes, M. (2007). İflasın ertelenmesi. Medeni Usul ve İcra Iflâs Hukukçuları Toplantısı II-III, Ankara: Türkiye Barolar Birliği Yayınları, 453- 527.

Özkan, Ö. (2008). Mahkemece iflasın ertelenmesi kararının verilmesinin şüpheli alacak karşılı̆g 1 ayrılmasına etkisi. ISMMMO Yayın Organı, Mali Çözüm Dergisi, 87.

Öztek, S. (2006). İflâsın ertelenmesi. Bankacılar Dergisi, 59, 39-83.

Seyfi, R. (2007). Sermaye şirketlerinde iflâsin ertelenmesi. Yüksek Lisans Tezi. Kayseri: Erciyes Üniversitesi.

Toplu, M. C. (2016). Ticari işletmelerde iflasın ertelenmesinde iyileştirme süreci ile borca batıklık tespitine yönelik değerlendirme. ISSMMMO Yayını, Mali Çözüm Dergisi, 59-73.

TTK (2011). 6102 Sayll Türk Ticaret Kanunu. (Erişim: 01/06/2017), http://www.mevzuat.gov.tr/MevzuatMetin 11.5.6102.pdf.

Uzay, Ş. (2008), Muhasebeci bakış açısı ile iflas erteleme süreci. (Erişim:25/12/2017), http://iibf.erciyes.edu.tr/ akademi/mh/suzay/SUZAY_IES.pdf.

Varıcı, İ. (2014). İflas ertelemesine başvuran şirketlerde kayyımın karşılaşabileceği muhasebe düzensizlikleri: kobi'lerde durum değerlendirmesi. Muhasebe ve Vergi Uygulamalart Dergisi, 2014/3.

Yıldız, B. (2016). İflasın ertelenmesi ve uzlaşma yoluyla yeniden yapılandırmada muhasebe meslek mensubunun rolü. Journal of Accounting, Finance and Auditing Studies, 192-223.

Y1lmaz, B. B. (2009). Iflasin tespiti ve ertelenmesi yönünden borca batıklık bilançosu ve iyileştirilmesi. Ankara: Türmob Yayınları. 